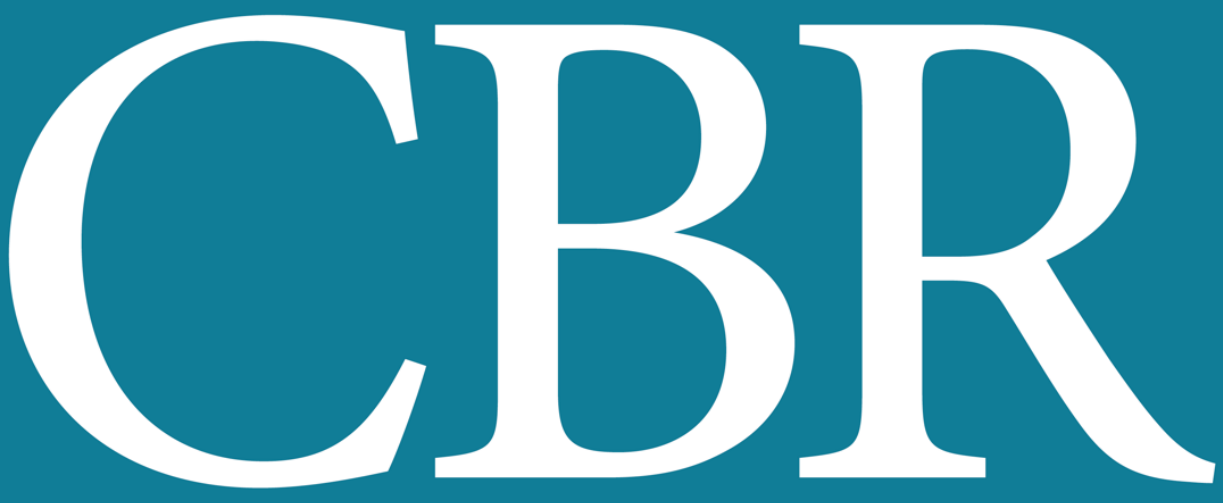

INTERNATIONAL JOURNAL OF CANCER AND BIOMEDICAL RESEARCH

https://jcbr.journals.ekb.eg

Editor-in-chief

Prof. Mohamed Labib Salem, PhD

Antitumor and antimicrobial activities of endophytic fungi obtained from Egyptian Urospermum picroides

Nessma A. El-Zawawy, Metwally A. Metwally, Noha Abd El-Salam 


\section{International Journal of Cancer \& Biomedical Research (IJCBR) https://jcbr.journals.ekb.eg}

IJCBR is an Int. journal published by the Egyptian Society of Cancer Research (EACR, established in 2014, http://eacr.tanta.edu.eg) and sponsored by the Egyptian Knowledge Bank (EKB: www.ekb.eg).

IJCBR has been approved by the Supreme Council of Universities, Egypt with score 7 (http://egjournal.scu.eg). The journl is cited by google scholar and registered by Publons (https://publons.com). The journal has recently been evaluated in 2020 by Nature Springer with a good standing.

\section{Scope of IJCBR}

- Drug discovery from natural and synthetic resources

- BioMedical applications of nanotehnology

- Sem cell biology and its application

- Basic and applied biotechnology

- Inflammation and autoimmune diseases

- In slico models and bioinformatics

- In vitro and In vivo preclinical animal models

- Cellular and molecular cancer biology

- Cancer Immunology and Immunotherapy

- New methods for prediction, early detection, diagnosis prognosis and treatment of dieases.

- Immunology in health and dieases

- Anti-microbial defense mechanisms

- Cellular and molecular physhiology and pahthology of diseases

\section{IJCBR Editor,}

Prof. Mohamed Labib Salem, PhD

Professor of Immunology

Faculty of Science, Tanta Universiy, Egypt 


\title{
Antitumor and antimicrobial activities of endophytic fungi obtained from Egyptian Urospermum picroides
}

\author{
Nessma A. El-Zawawy ${ }^{1}$, Metwally A. Metwally ${ }^{1}$, Noha Abd El-Salam ${ }^{2}$ \\ ${ }^{1}$ Botany Department, Faculty of Science, Tanta University, Tanta, Egypt \\ ${ }^{2}$ Research Center and Measurements, Tanta University, Tanta, Egypt
}

\section{ABSTRACT}

Urospermum picroides is a medicinal plant was founded in North coast, Egypt. Endophytic fungi of this medicinal plant in Egypt is poorly known and thus, this study aimed towards estimation of the biological activities of endophytic fungi from Egyptian U.picroides. Fusarium oxysporum and Phoma herbarum were isolated from U.picroides and identified based on phylogenetic analysis. Ethyl acetate extracts of F.oxysporum and P.herbarum gave high antioxidant activities (26.2 and 51.7\%, respectively). Moreover, they showed highly antitumor activities with some significant morphological changes of characteristic apoptosis accompanied by up regulation of both $\mathrm{p} 53$ and Bax for F.oxysporum and P.herbarum extracts $(1.55,2.14$ for $\mathrm{p} 53$ and 1.24, 2.2 for Bax, respectively) with down regulation of $\mathrm{Bcl}-2$ (0.18 and 0.16 , respectively). Ethyl acetate extract of F.oxysporum (EAFE) showed greatest antimicrobial activity against Trichophyton mentagrophytes $(70 \mathrm{~mm})$, while ethyl acetate extract of $P$.herbarum (EAPE) showed highest antimicrobial activity against Bacillus cereus $(37 \mathrm{~mm})$ and Candida albicans $(35 \mathrm{~mm})$. Scanning electron microscope micrographs showed major abnormalities for tested microorganisms after treatment with (EAFE and EAPE) resulting in complete alternation in their morphology. GC-MS results showed 30 biologically active compounds for both extracts. The most significant in EAFE was Diisooctyl phthalate with relative levels (74.9\%), while Benzoic acid, 3, 5-bis (1, 1-dimethylethyl)-4-hydroxy- was the most active compound in EAPE (61.7\%). These results proposed that ethyl acetate extracts of endophytic fungi from the Egyptian U.picroides showed to be promising novel as antioxidant, antitumor agents and antimicrobial with further phytochemical studies.

Keywords: Endophytic fungi, U. picroides, antioxidant, antitumor, antimicrobial

Editor-in-Chief: Prof. M.L. Salem, PhD - Article DOI: 10.21608/JCBR.2020.32713.1045
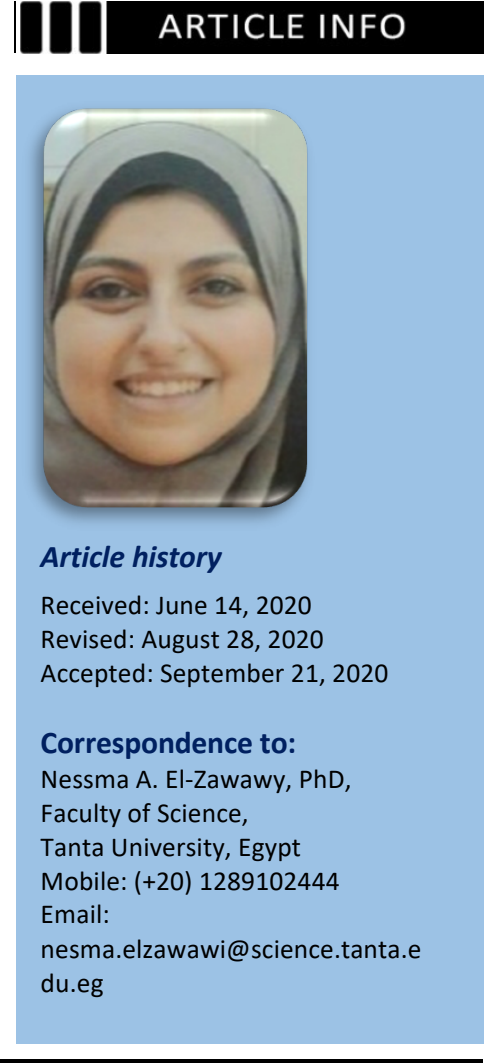

\section{INTRODUCTION}

Nowadays, many reports indicate that plants are considered as a repository of several microorganisms known as endophytes (Minirani et al., 2017). Endophytes are microorganisms that colonize plant for all or part of their life cycle. They live in inside plant tissues below the epidermal cell layers without causing any disease to their host and It looks like they could penetrate the living cells (Strobel and Daisy, 2003). Most endophytic fungi can synthesize bioactive variable compounds with antimicrobial, cytotoxic and anticancer activities (Kharwar et al., 2011) which become a hot spot of drug discovery.
Colletotrichum and Nigrospora spp endophytic fungal extracts isolated from Uvaria grandiflora have antibacterial, antioxidant and cytotoxic activity compared to mycelia extract (Israel et al., 2019). The Nile delta region is flourished by many weeds which seem to be promising raw materials in drug discovery. One of these weeds is $U$. picroides which is a Mediterranean annual herb of flowering plant in the family Asteraceae was known by the common name prickly golden fleece. Previous studies suggested that this plant's root, flower and stem extracts are effective as an antimicrobial (El-Ghazooly et al., 2003). Nevertheless, little is known about endophytic fungi isolated from U. picroides. 
Owing to our knowledge, our study was considered the first study to isolate and identify these two endophytic fungi from $U$. picroides reporting their antimicrobial, antioxidant and antitumor activities and their effect on expressed tumor genes showing their apoptotic effect.

\section{MATERIAL AND METHODS Collection of host plants}

$U$. picroides was collected from different areas in North coast, Alexandria, Egypt at October 2017 (Figure 1S). The identification of species was done according to Ahmed (2003). Plant flowers were cut, separated, dried and saved in plastic bags. Hold the samples at $4^{\circ} \mathrm{C}$ before fungal endophytes can be isolated.

\section{Isolation of endophytic fungi}

Based on the procedures mentioned by Xu et al. (2008), isolation of the endophytic fungi was carried out. The plant samples were cut into small cubes and then surface-disinfected for 1 min by washing in 75 percent ethanol, sterile distilled water twice, $0.05 \mathrm{~g} / \mathrm{ml}$ sodium hypochlorite solution for $3 \mathrm{~min}$, followed by two rinses in sterile distilled water. The surfacesterilized samples were cut into small pieces using a sterile blade and positioned for incubation at $25^{\circ} \mathrm{C}$ on plates with potato dextrose agar (PDA). The endophytic fungi that were immersed from the tissues were transferred to new PDA dishes and sequential subculturing was performed until the identification of pure cultures was obtained.

\section{Identification and phylogenetic analysis of endophytic fungi}

Fungal identification was based on their internal transcribed spacer ribosomal DNA (ITSrDNA) sequences at Mubarak city for scientific research. A pair of primers ITS1 (sequence: $5^{\prime}$ TCC GTA GGT GAA CCT GCG G-3') and ITS4 (5'TCC TCC GCT TAT TGA TAT GC-3') was used for ITS-rDNA amplification (Phongpaichit et al., 2006)]. The corresponding ITS-rDNA sequence of each endophytic fungus (Table 1S) was then used for similarity analysis using BlastN algorithm against the public database at the National Center for Biotechnology Information (NCBI; http://www.ncbi.nlm.nih.gov). Multiple sequence alignments were performed using the
CLUSTALW program (Thompson et al., 1994). Molecular evolutionary analyses were conducted using MEGA version 10.0.4. The phylogenetic trees were constructed using the neighbor-joining (NJ) algorithm (Naruya and Masatoshi, 1987).

Table 1. IC 50 values $(\mu \mathrm{g} / \mathrm{ml})$ of antitumor activities of EAFE and EAFE.

\begin{tabular}{|l|c|c|}
\hline \multirow{2}{*}{ Tested material } & \multicolumn{2}{|c|}{ IC $_{\mathbf{5 0}}(\boldsymbol{\mu g} / \mathbf{m l})$} \\
\cline { 2 - 3 } & $\mathbf{2 4}$ hours & $\mathbf{4 8}$ hours \\
\hline F. oxysporum extract & $1269 \pm 0.002$ & $645.7 \pm 0.004$ \\
P. herbarum extract & $1590 \pm 0.003$ & $627 \pm 0.004$ \\
\hline Doxorubicin & $0.5 \pm 0.03$ & $0.3 \pm 0.05$ \\
\hline
\end{tabular}

\section{Preparation of fungal fermentation broth}

The two endophytic fungal isolates identified were cultivated at $25^{\circ} \mathrm{C}$ for 10 days in potato dextrose liquid medium. The crude fermentation broth was thoroughly blended for each isolate $(107 \mathrm{CFU} / \mathrm{ml})$ and centrifuged for 5 minutes at $4000 \mathrm{r} / \mathrm{min}$. Liquid supernatant has been extracted with an equal amount of thrice ethyl acetate. The organic solvent extract was then evaporated under reduced pressure to produce two fungal extracts of ethyl acetate (TEAFEs) for screening antioxidant, antitumor and antimicrobial activities (Lv et al., 2010).

\section{Antioxidant activity assay}

The antioxidant activities of TEAFEs were determined by using the free radical scavenging method (DPPH) characterized by El-Amier et al. (2016). $2 \mathrm{ml}$ of $0.15 \mathrm{mM}$ DPPH has been added to $2 \mathrm{ml}$ of different TEAFE concentrations $(5,10$, $20,25,50,75 \mu \mathrm{g} / \mathrm{ml}$ ). A control was prepared in place of the sample by adding $2 \mathrm{ml}$ solvent. At room temperature, the mixture was incubated in dark for $30 \mathrm{~min}$. The absorbance was estimated at $517 \mathrm{~nm}$, and graphically determined IC50. The estimation of antioxidant activity took the following equation:

$\%$ Radical scavenging activity $=\left(A_{\circ}-A_{s} / A_{\circ}\right) \times 100$

where $A_{0}$ : is blank absorbance, $A_{s:}$ is sample absorbance at $517 \mathrm{~nm}$.

\section{Antitumor activity assay}

Mosman and Alley tested antitumor activity in vitro using MTT assay (Mosmam, 1983; Alley et al.,1988) with minor modification on Human liver tumor cell line (HepG2) obtained from 
Medical Research Institute (MRI), Alexandria University, Alexandria, Egypt. Briefly, HepG2 cells were seeded in 96 well plates of microculture $(90 \mu \mathrm{l} /$ well), and before sample addition, it was permitted to adhere overnight. The samples were applied to tumor cells (10 $\mu \mathrm{l} /$ well) with different concentrations of TEAFEs $(200,400,600,1000,1200,1500,1700 \mu \mathrm{g} / \mathrm{ml})$ in comparison to doxorubicin (chemotherapy) at different concentrations $(0.21,0.42,0.85$, $1.7,3.4 \mu \mathrm{g} / \mathrm{ml})$. Then incubated in a humidified $5 \% \mathrm{CO} 2$ incubator at $37^{\circ} \mathrm{C}$ for 24 and 48 hours. Analysis of each concentration in triplicate wells. At the end of the exposure, $20 \mu \mathrm{l}$ of 5 $\mathrm{mg} / \mathrm{ml} \mathrm{MTT}$ has been applied to each well and the plates have been incubated at $37^{\circ} \mathrm{C}$ for 4 hours, then apply acidified isopropanol to crystal dissolve, shaking for $10 \mathrm{~min}$. The optical density (OD) was read at a $630 \mathrm{~nm}$ wave-length on a plate screen. The growth inhibition rate was calculated by the following equation:

Growth inhibition rate $\%=$

$\left(O D_{\text {control } /} \mathrm{OD}_{\text {trated }}\right) / O D_{\text {control }} \times 100 \%$

Gene expression \& apoptotic effect of TEAFEs using quantitative PCR

Three groups were used as the following: Control group (negative control) contained HepG2 with density $0.5 \times 10^{5} / \mathrm{ml}$ and (DEMEM) complete media, the other two groups contained HepG2 with the same density $0.5 \times 10^{5} / \mathrm{ml}$ and $4 \mathrm{ml}$ of complete DEMEM media containing the concentration of TEAFEs with $\mathrm{IC}_{50}$ at 48 hours, After incubation for 48 hours, RNA of control and treated cells were extracted using the commercial kits (Thermo scientific Gene JET RNA Co, \#k0731, America) protocol. First cDNA strand was synthesized using RT-for-PCR advantage kit (SensiFAST ${ }^{\mathrm{TM}}$ CDNA Synthesis Kit Thermo Co, BIO-6505, America). The first-strand cDNA was used as a template in the PCR experiment to detect genes ( $\mathrm{p} 53$, Bax and $\mathrm{Bcl}-2$ ) using three primers designed by PRIMERPLAST (https://blast.ncbi.nlm.nih.gov/Blast.cgi) (Table 2S) according to (Yu et al., 2003; Yang et al., 2010), respectively. Quantitative PCR is performed in a qRT-PCR (Rotor 5 plex QIAGEN gene). The GAPDH gene was utilized in the study as a housekeeping gene (reference gene).
Table 2. Inhibitory effect of different concentrations of EAFE and EAPE against different tested microorganisms

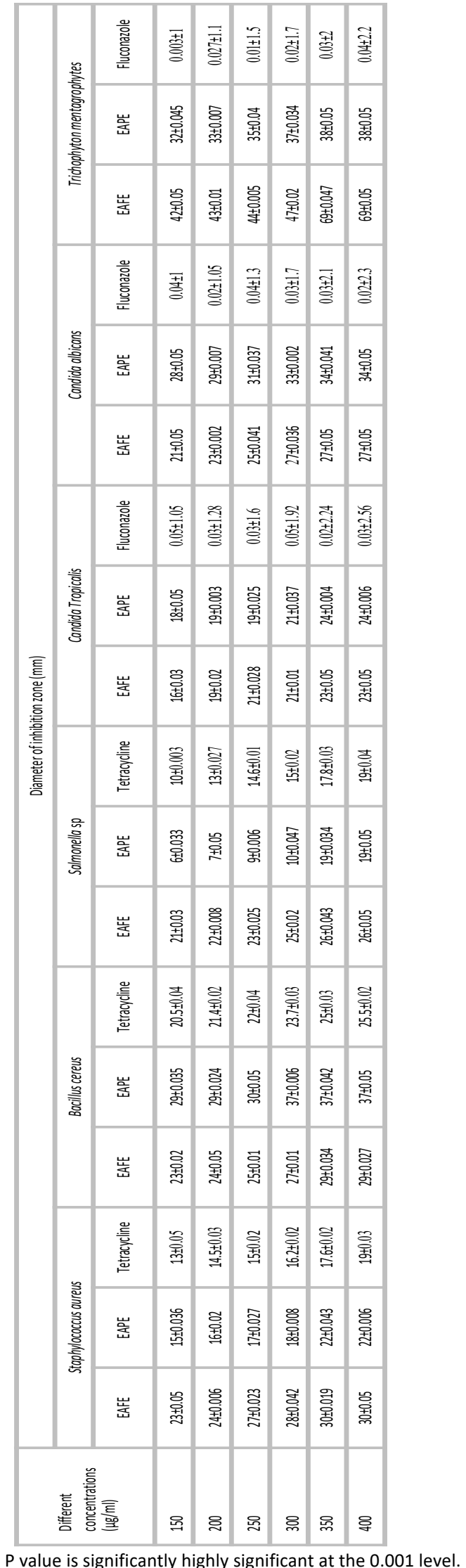




\section{Antimicrobial activity assay}

Antimicrobial activities of TEAFEs were measured using the modified agar well diffusion method. Different concentrations of TEAFEs $(150,200,250,300,350,400 \mu \mathrm{g} / \mathrm{ml})$ were prepared compared to antifungal Fluconazole (Diflucan, Pfizer) and antibacterial Tetracycline (Thiophenicol, Sonafi aventis) and tested as a positive control in the same concentrations. One hundred micro liters of Bacillus cereus, Staphylococcus aureus, Salmonella sp, the pathogenic fungus Candida albicans, Candida tropicalis and the pathogenic dermatophytes Trichophyton mentagrophytes $\left(10^{5} \mathrm{CFU} / \mathrm{ml}\right)$ were inoculated on nutrient agar medium for bacterial isolates and SDA medium for candidal isolates and Sabouraud dextrose agar supplemented with cycloheximide $(0.1 \%)$ for dermatophytes.

After inoculation of each isolate on plates of its media, regular wells were made aseptically filled up with $0.1 \mathrm{ml}$ of different concentrations. The plates were incubated for $24 \mathrm{~h}$ at $37^{\circ} \mathrm{C}$ (Gokhale et al., 2017). The experiments were performed in triplicate. According to Radhika et al. (2008), MIC of the highest antimicrobial extract was calculated and identified as the lowest concentration at which growth was completely inhibited.

\section{Scanning electron microscope}

The electron microscope was used to investigate the mechanism of action of the most effective antimicrobial extracts of TEAFEs on Bacillus cereus, Candida albicans and Trichophyton mentagrophytes. The sample preparation for SEM was done according to Kaya et al. (2008). Small agar pieces from isolates were cut from the inhibition zone and they were fixed in $3 \%(\mathrm{v} / \mathrm{v})$ glutaraldehyde buffered with $0.1 \mathrm{M}$ sodium phosphate buffer (PH 7.2) for an hr. at room temperature, then washed four times in sodium phosphate buffer. The pieces were then post-fixed in $1 \%(\mathrm{~W} / \mathrm{V})$ osmium tetroxide $\left(\mathrm{OsO}_{4}\right)$ for an hr., then washed four times in the buffer. They were dehydrated in a graded alcohol series. The last stages of dehydration were performed with propylene oxide $\left(\mathrm{CH}_{3} \mathrm{CH} . \mathrm{CH}_{2} . \mathrm{O}\right)$.
The specimens were dried and were mounted onto stubs using double-sided carbon tape, and then were coated with a thin layer of gold by a sputter coater (DII-29030SCTR smart coater) then examined by scanning electron microscope (JEOL (JSM IT 100,30KV,300.000x) at Nano scientific technology institute, the University of Kafr El-Sheik, Kafr El-Sheik, Egypt.

\section{Identification of bioactive metabolites by GC-} MS analysis

Study of GC-MS for TEAFEs was performed at Center of Scientific Research and Measurements, Tanta University, Tanta, Egypt The Perkin Elmer model:(Clarus 580/560 S) was used in the column analysis (Rxi-5Sil MS column $30 \mathrm{~m}, 0.25 \mathrm{~mm}$ ID, $0.25 \mathrm{df}$ ) and the components were separated at a constant flow of $1 \mathrm{ml} / \mathrm{min}$ using helium as a carrier gas. During chromatographic run the temperature of the injector was set at $280^{\circ} \mathrm{C} .1 \mu \mathrm{l}$ of extract sample was injected into the scanning instrument for 30 $\mathrm{min}$, initial oven temperature $60^{\circ} \mathrm{C}$ for $10 \mathrm{~min}$, ramp $10^{\circ} \mathrm{C} / \mathrm{min}$ to $280^{\circ} \mathrm{C}$ for $6 \mathrm{~min}$, split $20: 1$, solvent delay $=3 \mathrm{~min}$. The conditions for the mass detector were transferred line temperature $280^{\circ} \mathrm{C}$, ion source temperature $200^{\circ} \mathrm{C}$, and the effect of ionization mod electron at $70 \mathrm{eV}$, a scan time of 0.2 sand scan-interval of 0.1 s. Given fragments from 50 to $600 \mathrm{Da}$, the component spectrum was compared with the spectrum database of recognized components held in the GC-MS NIST library (Rukshana et al., 2017).

\section{Statistical analysis}

Statistical analysis was conducted for the studied data of TEAFE extracts on microorganisms and tumor cells through the SPSS V17 one-way test of variance analysis (ANOVA), to evaluate the variation between the concentrations of both extracts.

\section{RESULTS}

\section{Isolation and identification of endophytic fungi}

Two endophytic fungi were isolated from flowers of $U$. picroides. Based on the results of molecular identification (Figure 1) these two fungi were identified as F.oxysporum and P.herbarum. Reports on the biological activities of F.oxysporum and P.herbarum as endophytic fungi from Egyptian U.picroides have been 
documented to the best of author's knowledge. Therefore, this study was aimed at assessing the antioxidant, antitumor and antimicrobial activities of these two endophytic fungi.

\section{Antioxidant activity}

Ethyl acetate extracts of F.oxysporum (EAFE) and P.herbarum (EAPE) exhibited significantly higher antioxidant activities as shown in Figure 2. It was observed that the scavenging activity of the two extracts increased gradually by increasing concentration. EAPE showed the highest antioxidant activity (51.7\%) followed by EAFE (26.2 \%) opposed to ascorbic acid as a standard (24.5\%) at a concentration of (75 $\mu \mathrm{g} / \mathrm{ml})$.

\section{Antitumor activity}

In vitro, the highly antitumor activity of TEAFEs against HepG2 cells at different concentrations $(200,400,600,800,1000,1200,1500$, $1700 \mu \mathrm{g} / \mathrm{ml}$ ) after 24 and 48 hours incubation compared to doxorubicin as chemotherapy was shown in (Figure 3). IC 50 of EAFE and EAPE were $1269 \mu \mathrm{g} / \mathrm{ml}, 1590 \mu \mathrm{g} / \mathrm{ml}$ after 24 hours and $645.7 \mu \mathrm{g} / \mathrm{ml}, 627 \mu \mathrm{g} / \mathrm{ml}$ after 48 hours, respectively (Table 1 ).

\section{Morphologic changes in cells treated with HepG2}

The morphological examinations of the HepG2 cells treated with $\mathrm{IC}_{50}$ doses for 48 hours of EAFE and EAPE (Figure 4). Treated cells (Figure 4b, c) showed significant morphological changes, which were characteristic of apoptosis, such as cell swelling, shrinkage and reduced in growth with the destruction of monolayer which was not seen in untreated HepG2 cells (Figure 4a).

\section{Gene expression \& apoptotic effect of TEAFEs using quantitative PCR}

The expression of p53, Bax, and Bcl-2 was expressed in treated HepG2 cells with 48-hour TEAFE IC $\mathrm{C}_{50}$ and control untreated HepG 2 cells in (Figure 5). The transcription rate induced in HEPG2 cells was analyzed compared with control cells by the change in relative quantity (RQ) or relative concentration in the treated HepG2 cells. The RQ values (fold change) obtained from the expression of p53 in treated HepG2 cells with EAFE and EAPE concentration IC50 were up to 1.55 and 2.14, compared to control untreated cells in HepG2 treated cells, respectively.

In addition, RQ values obtained from Bax expression in treated HepG2 cells with IC50 concentration of the two extracts were up to 1.24 and 2.2 for EAFE, EAPE, compared to control untreated cells in HepG2 treated cells, respectively. In HepG2 treated cells with IC50 concentration of EAFE a-nd EAPE, expression of $\mathrm{Bcl}-2$ was reduced to 0.18 and 0.16 compared to control untreated cells in HepG2 treated cells.

Antimicrobial screening of ethyl acetate extracts produced by endophytic fungi

The inhibitory effect of different concentrations of TEAFEs against different microorganisms was shown in (Table 2). EAFE gave the greatest inhibition zone at a concentration $(150 \mu \mathrm{g} / \mathrm{ml})$ against Trichophyton mentagrophytes $(42 \mathrm{~mm})$ compared to Fluconazole followed up by Staphylococcus aureus and Bacillus cereus which measure $(23 \mathrm{~mm})$ for both compared to tetracycline. While EAPE gave the greatest inhibition zone at a concentration $(150 \mu \mathrm{g} / \mathrm{ml})$ against Trichophyton mentagrophytes $(32 \mathrm{~mm}$ ) followed by Bacillus cereus which measure (29 $\mathrm{mm}$ ) and Candida albicans (28 mm). MIC value of EAFE for Staphylococcus aureus, Bacillus cereus, Candida tropicalis and Trichophyton mentagrophytes is $350 \mu \mathrm{g} / \mathrm{ml}$ which considered as MIC value with inhibition zones of $(30,29,23$ and $69 \mathrm{~mm}$ ), respectively. However, $300 \mu \mathrm{g} / \mathrm{ml}$ of EAFE was recorded as MIC against Salmonella $\mathrm{sp}$ and Candida albicans with inhibition zones (26 and $27 \mathrm{~mm}$ ), respectively (Table 1). While, MIC was detected in (EAPE) at a concentration of $350 \mu \mathrm{g} / \mathrm{ml}$ against Staphylococcus aureus, Salmonella sp and Trichophyton mentagrophytes with inhibition zones of $(22,19$ and $38 \mathrm{~mm}$ ), respectively. While $300 \mu \mathrm{g} / \mathrm{ml}$ of EAPE was recorded as MIC against Bacillus cereus, Candida tropicalis and Candida albicans with inhibition zones $(37,21$ and $33 \mathrm{~mm})$, respectively.

\section{Scanning electron microscopy}

Morphological alternations of Candida albicans, Bacillus cereus and Trichophyton mentagrophytes after treated with TEAFEs extracts were shown on SEM micrographs. In $C$. albicans, The EAPE cells had subjected distinct 
morphological and cytological alternations. While control cells showed the normal structure of Candida cells. When the Bacillus cereus cells treated with EAPE were compared with untreated cells, the cells being treated seemed to be shrinking and there was a degradation of the cell wall and the cells were depressed from the middle as appeared in (Figure 6). Several changes in hyphae of treated Trichophyton mentagrophytes with EAFE, as it appeared shrinked with a rough surface, a flat ribbonshaped structure with the demolition of the cell wall, cell wall thickening and disordered hyphal tip. However, the normal cells have smooth, thick-ring- shaped septum and stable surface decoration (Figure 7).

\section{Identification of bioactive metabolites by GC- MS analysis}

GC-MS is the best techniques for distinguishing the components of volatile matter, long chain, branched hydrocarbons, acids of alcohols, esters etc. The active principles were presented in percentage with their retention time (RT), molecular formula, molecular weight (MW), and peak area in (Table 3). GC-MS analysis of EAFE showed Diisooctyl phthalate was the most active compound. Whereas Benzoic acid, 3, 5bis (1,1-dimethylethyl)-4-hydroxy- was the most active compound in EAPE as in (Table 4).

Table 3. Mass fractions of EAFE identified by GC-MS.

\begin{tabular}{|c|c|c|c|}
\hline $\begin{array}{l}\text { No. } \\
\text { (min) }\end{array}$ & RT & Compounds & $\begin{array}{l}\text { Relative } \\
\text { proportion } \\
\text { (\%) }\end{array}$ \\
\hline 1. & 5.494 & p-Xylene & 26.9 \\
\hline 2. & 5.704 & Heptane, 3,4-dimethyl- & 21.8 \\
\hline 3. & 14.347 & Ans- pro & 9.7 \\
\hline 4. & 14.552 & Maprotiline & 16.9 \\
\hline 5. & 14.627 & Cinnamic acid, p-(trimethylsiloxy)-, methyl ester & 22.8 \\
\hline 6. & 14.767 & 3,5-Di-t-butyl-4-methoxy-1,4-dihydrobenzaldehyde & 15 \\
\hline 7. & 14.937 & Perylene & 11.1 \\
\hline 8. & 14.967 & 4-(1,1-Dimethylpropyl)phenol, trimethy-I silyl ether & 26.3 \\
\hline 9. & 15.218 & Tyr-Ala(Dstereo) & 25.3 \\
\hline 10. & 15.268 & Diclofenac & 26.7 \\
\hline 11. & 15.398 & Benzo[e]pyrene & 27 \\
\hline 12. & 15.598 & Maprotiline-M (desamino-di-HO-) & 3.8 \\
\hline 13. & 16.068 & $\begin{array}{l}\text { 6-Quinazolinecarboxamide,1,2,3,4-tetrahydro-1,3dimethyl-2,4-dioxo-N-(2- } \\
\text { phenylethyl) }\end{array}$ & 10.2 \\
\hline 14. & 16.173 & Disperse Blue 26 & 34.7 \\
\hline 15. & 16.423 & Benzo[b]naphtho[2,3-d]thiophene, 9,10-dihydro-7methyl & 12.6 \\
\hline 16. & 16.468 & Silane,9anthracenyltrimethyl- & 13.3 \\
\hline 17. & 17.078 & Methaqualone & 9.6 \\
\hline 18. & 18.789 & 1,1'-Biphenyl, 2,4-dichloro-2',5'-dimethyl- & 9.5 \\
\hline 19. & 30.449 & Heptadecane, 9-hexyl- & 5.1 \\
\hline 20. & 31.229 & Di-n-decylsulfone & 13.4 \\
\hline 21. & 31.509 & Diisooctyl phthalate & 54.6 \\
\hline 22. & 31.794 & 3-Benzo[g]quinoxalin-2-yl-propionic acid & 32 \\
\hline 23. & 31.824 & Asn-Pro & 5.4 \\
\hline 24. & 32.019 & 2,2-Dimethyleicosane & 5.3 \\
\hline 25. & 32.815 & Oxalic acid, allyl pentadecyl este & 6.6 \\
\hline 26. & 33.765 & 1-Hexadecanol, 2-methyl- & 4.1 \\
\hline 27. & 34.290 & Bismuthine, tripropyl- & 22 \\
\hline 28. & 34.851 & Di-n-decylsulfone & 16.1 \\
\hline 29. & 36.161 & 1,4-Naphthoquinone, 6-ethyl-2,3,5,7-tetrahydroxy- & 27.1 \\
\hline 30. & 36.446 & Pendimethalin & 19.9 \\
\hline
\end{tabular}


Table 4. Mass fractions of EAPE identified by GC-MS.

\begin{tabular}{|c|c|c|c|}
\hline No. & RT (min) & Compounds & Relative proportion (\%) \\
\hline 1. & 5.97 & Tyr-Ala(Dstereo) & 3.6 \\
\hline 2. & 6.03 & 4-Methoxy-N,N-bis-trimethylsilyl-aniline & 6.6 \\
\hline 3. & 6.29 & Glu-Ser & 4.7 \\
\hline 4. & 6.53 & 1,2-Dimethyl-4,5-bis(trimethylsilyl)benzene & 5.6 \\
\hline 5. & 6.7 & -4'-Dimethylamino-2'-(trimethylsilyl)acetanilide & 9.8 \\
\hline 6. & 6.79 & Cinnamic acid, m-(trimethylsiloxy)-, methyl ester & 2.3 \\
\hline 7. & 6.86 & Zolpidem & 13.6 \\
\hline 8. & 6.95 & Phethalic acid, monoamide, $\mathrm{N} \mathrm{N}^{\prime}$-diphenyl & 15.1 \\
\hline 9. & 7.18 & 1-Methyl-2,5-dichloro-1,6-diazaphenalene & 10.6 \\
\hline 10. & 7.27 & Benzo[e]pyrene & 8 \\
\hline 11. & 7.34 & Cinnamic acid,p-(trimethylsiloxy)-,methyl ester & 14.9 \\
\hline 12. & 7.41 & 2-Myristynoyl-glycinamide & 16.3 \\
\hline 13. & 7.68 & Asn-Pro & 2.8 \\
\hline 14. & 7.71 & Disperse Blue 26 & 8.7 \\
\hline 15. & 7.86 & Pyrazole-3-carboxylic acid, 4-iodo-1-methyl- & 0.3 \\
\hline 16. & 8.05 & Adenylosuccinic acid & 2.6 \\
\hline 17. & 8.15 & Metolachor & 5.5 \\
\hline 18. & 8.3 & Tyr-Ala(Dstereo) & 7 \\
\hline 19. & 8.66 & 2-chloro-3-methoxydibenzo-p-dioxin & 8.1 \\
\hline 20. & 8.97 & Tyr-Ala(Dstereo) & 3.2 \\
\hline 21. & 9.01 & 1,4-Naphthoquinone,6-ethyl-2,3,5,7-tetrahydroxy- & 8.2 \\
\hline 22. & 9.18 & Tyr-Ala(Dstereo) & 3.1 \\
\hline 23. & 9.56 & 5-Methyl-4'-hydroxy-2-benzylidene-coumaran-3-one & 11.9 \\
\hline 24. & 9.66 & Tyr-Ala(Dstereo) & 1.5 \\
\hline 25. & 9.83 & Halosulfuron-methy & 12.1 \\
\hline 26. & 10.47 & Benzimidazole-5-carboxylic acid, 2-methyl-1-phenyl & 2.4 \\
\hline 27. & 10.61 & Maprotiline & 11.8 \\
\hline 28. & 10.92 & Tyr-Ala(Dstereo) & 3.6 \\
\hline 29. & 11.89 & Benzene,1-methoxy-3-[3-(trimethylsilyl)methyl-3-butenyl]- & 7 \\
\hline 30. & 23.04 & Benzoic acid, 3, 5-bis(1, 1-dimethylethyl)-4-hydroxy-methyl ester & 26 \\
\hline
\end{tabular}

\section{DISCUSSION}

Mycologists have used the name endophytes for fungi that occupy live, internal plant tissues without causing symptoms of the disease. Endophytic fungi that live inside plant tissues were present in virtually all species of plants (Glienke-Blanco et al., 2002). Many economically important grasses carry fungal endophytes which may enhance host growth, may improve the ability of plants to tolerate abiotic stress, like drought, as well as improve their resistance to insect and mammalian herbivores (Huang et al., 2008). Some endophytes protect their host from insect by producing bioactive metabolites(Jalgaonwala et al., 2010). In addition, some of these compounds have proved useful as leads for the discovery of novel drugs (Yadav et al., 2014). Endophytic fungi contain several bioactive metabolites that are used to treat wound burn infections and have a wide range of medicinal properties such as antimicrobial and antitumor activity (Aly et al., 2008). Endophytes and their secondary metabolites therefore not only play an important ecological role but also have a positive impact on the medical sector. Also, their bioactive metabolites can be used as immunosuppressant, anticancer and biocontrol agent (Selvin et al., 2004).

In our study, F.oxysporum and P.herbarum were isolated and identified in similar to Cui et al. (2011) who isolated Fusarium sp. from Aquilaria sinensis and Khan et al. (2014) who identified Phoma $s p$. as an endophytic fungus from Moringa peregrine. In this study, TEAFEs demonstrated high dose-dependent scavenging activity of DPPH radical compared with ascorbic acid as a standard, in accordance to Li et al. (2011) who reported that water extract of endophytic F.oxysporum from Dioscoreazin giberensis gave high antioxidant activity reached to $(84.27 \%)$. 
A
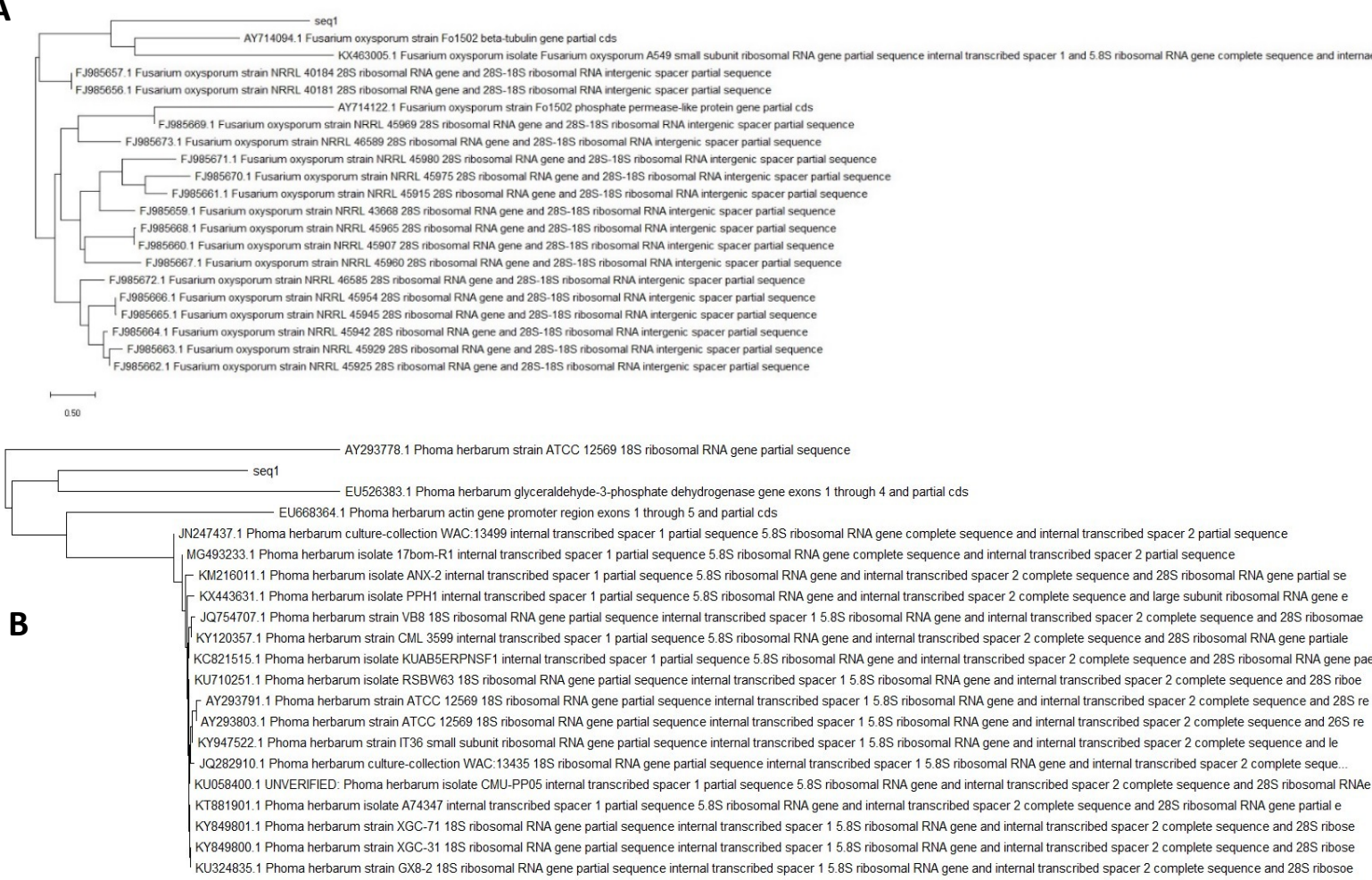

Figure 1. Phylogenetic analysis of isolated Fusarium oxysporum and Phoma herbarum from urospermum picroides (medicinal plant). A: Phylogenetic tree of isolated F.oxysporum. B: Phylogenetic tree of isolated Phoma herbarum. Both of Trees were constructed based on their internal transcribed spacer ribosomal DNA (ITSrDNA) sequences. The phylogenetic trees were constructed using the neighbor-joining (NJ) algorithm. Multiple sequence alignments were performed using the CLUSTALW program. Molecular evolutionary analyses were conducted using MEGA version 10.0.4.

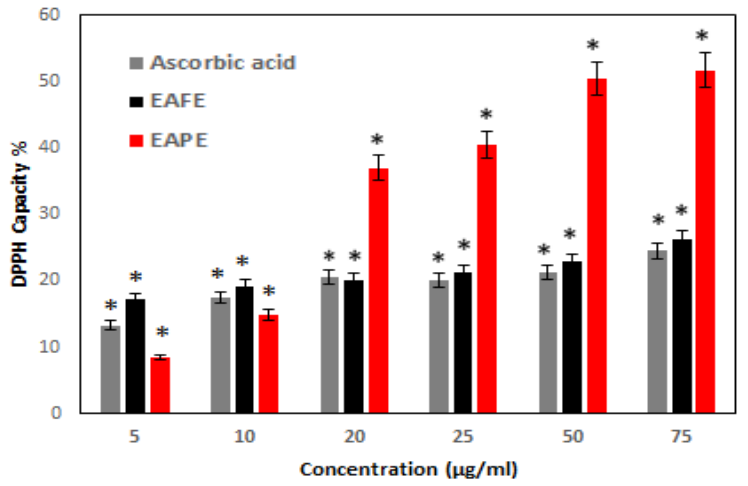

Figure 2. Quantitative analysis for antioxidant activity of EAFE and EAPE in comparison to ascorbic acid. EAFE: Ethyl acetate Fusarium Extract and EAPE: Ethyl acetate Phoma Extract. EAPE showed a potent antioxidant activity (51.7\%) followed by EAFE (26.2\%) compared to ascorbic acid (positive control) (24.5\%) at a concentration of $(75 \mu \mathrm{g} / \mathrm{ml}$ ). Data are expressed as Mean \pm SD. $(n=3)$ of three independent experimental replicates. *Statistically significant antioxidant activities of EAFE and EAPE in relation to ascorbic acid (normal control). The data were statistically analyzed by Graph pad prism (version 5.01) indicating that the data were significant with P-value $\leq$ 0.05 .
Moreover, polysaccharides from endophytic P.herbarum showed highly significant antioxidant activity (Yang et al., 2005). Similarly, Huang et al. (2001) declared that F.oxysporum and P.herbarum as Taxus mairei and Torreya grandis endophytic fungi showed antitumor activity against BGC-823 cell line (Human gastric tumor cells). Further study by Minirani et al. (2017) showed anticancer activity of endophytic fungal extracts from Annonam uricata against MCF-7 cells with the same morphological changes in our study. Moreover, in accordance with our results, many morphological changes in treated HepG2 cells with Terminalia arjuna bark extract were reported by Sivalokanathan et al. (2006). These studies strongly supported our findings that endophytic medicinal plant fungi are a promising source of natural active antitumor compounds. 


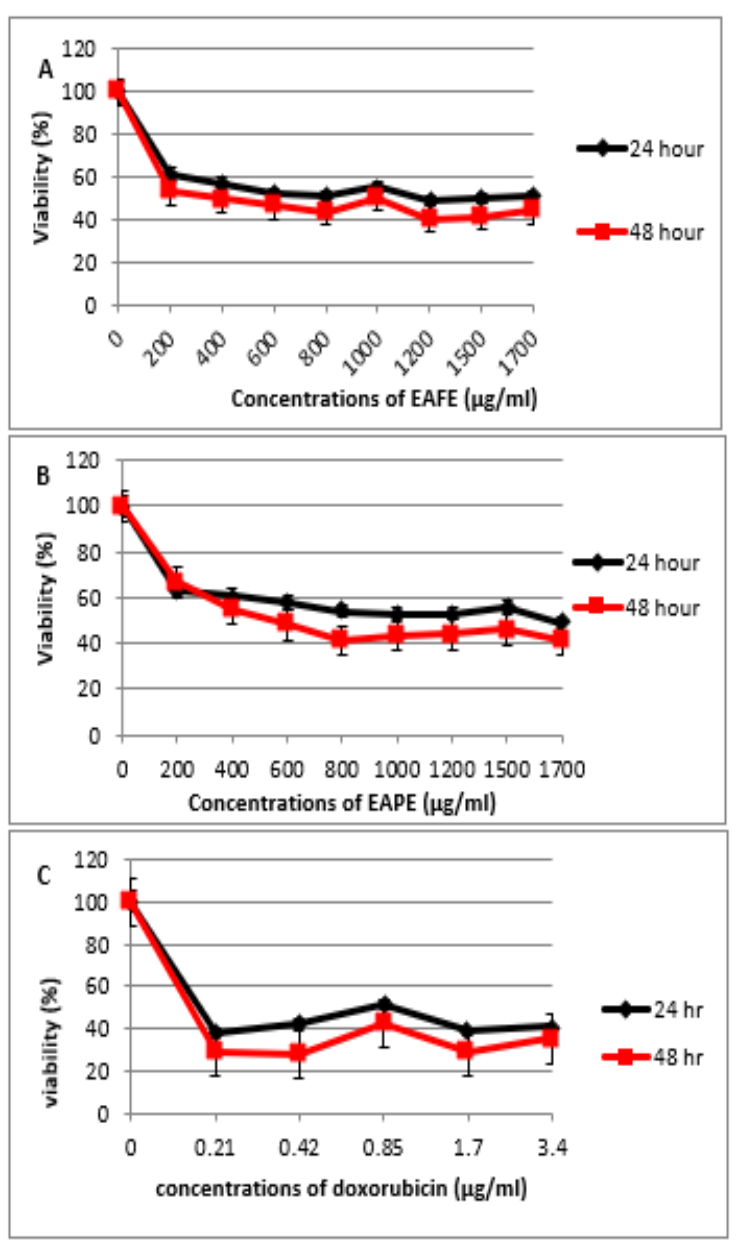

Figure 3. Quantitative analysis of anti-tumor activities of fungal extracts in comparison to doxorubicin against liver cancer cell line (HepG2). A: EAFE (Ethyl Acetate Fusarium Extract), B: EAPE (Ethyl Acetate Phoma Extract) and C: Doxorubicin. Both of extracts (EAFE and EAPE) showed highly antitumor activities with IC50\% $(1269,1590 \mu \mathrm{g} / \mathrm{ml})$ after 24 hours and $(645.7,627 \mu \mathrm{g} / \mathrm{ml})$ after 48 hours, respectively. Data are expressed as Mean \pm SD. $(n=3)$ of three independent experimental replicates. *Statistically significant antitumor activities of EAFE and EAPE in relation to doxorubicin (positive control). *P-value: versus nontreated control group; * all data is analyzed by Graph pad prism (version 5.01) significantly different as compared to non-treated control cell at $\mathrm{P}<0.05$.

Our study was the first study to study the gene expression and apoptotic markers of Fusarium $\mathrm{sp}$ and Phoma sp extracts which isolated from $U$. picroides using quantitative real-time PCR on Human liver cancer cell line (HepG2). which showed up of Bax regulation and $\mathrm{p} 53$ regulation and down of $\mathrm{BCl}-2$ regulation. Similarly, as in Eurycomalo ngifolia (Zakaria et al., 2009) and Solanum nigrum (Yb et al., 2008), several researchers reported induction of apoptosis in HepG2 cells through the up regulation of $p 53$ and $\mathrm{Bax}$, and down regulation of $\mathrm{Bcl}-2$.
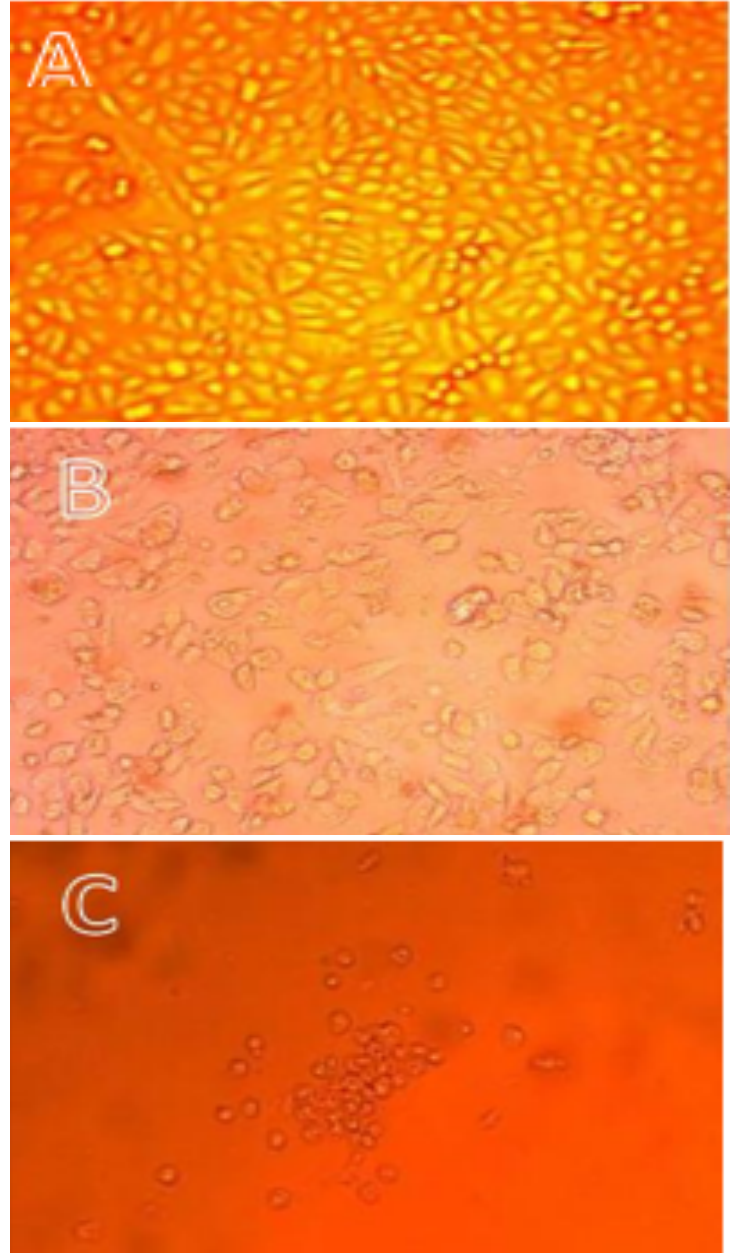

Figure 4. HepG2 liver-cancer cells treated with extract of two types of endophytic fungi. $A=$ control, HepG2 livercancer cells without treatment, B = HepG2 liver -cancer cells treated with EAFE (Ethyl acetate Fusarium Extract) at a concentration of $645.7 \mu \mathrm{g} / \mathrm{ml}, \mathrm{C}=\mathrm{HEPG} 2$ liver-cancer cells treated with EAPE (Ethyl Acetate Phoma Extract) at a concentration of $627 \mu \mathrm{g} / \mathrm{ml}$ (20xmagnification). Treated cells showed significant morphological changes, which were characteristic of apoptosis, such as cell swelling, shrinkage and reduced in growth with the destruction of monolayer which was not seen in untreated HepG2 cells.

The TEAEs showed high antimicrobial activities which showed morphological alternations by SEM. Rantaweera et al. (2015), which examined the antimicrobial properties of endophytic fungi obtained from Opuntia dillenii, accordingly. Furthermore, some morphological changes appeared on Cryptococcus neoformans, Candida albicans and Microsporum gypseum treated with endophytic fungal extracts of Penicillium sp. Fusarium sp. Trichoderma sp and Hypocreales sp using scanning electron microscope as the cells seemed to shrink, and the cell wall degraded (Supaphon et al., 2013). 


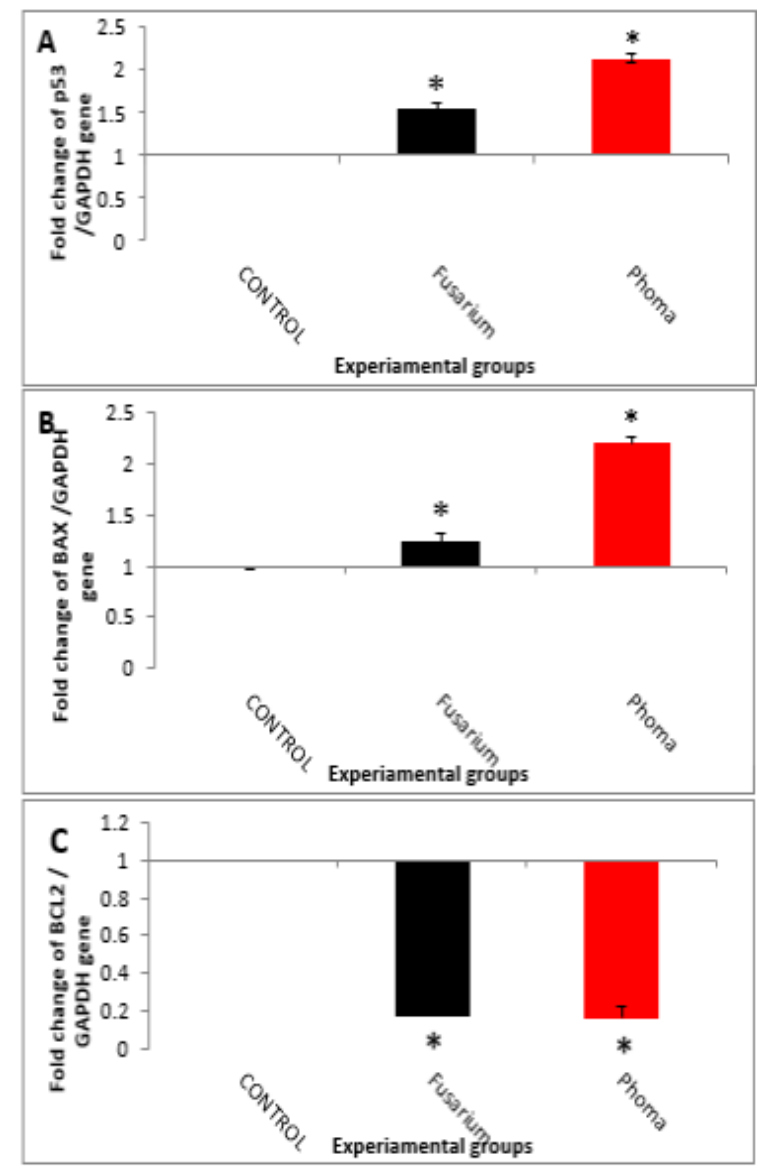

Figure 5. Quantitative analysis of gene expression of apoptotic markers on different treatments on HepG2 (liver cancer cells).p53 and Bax tumor marker genes indicated high expression in treatments with the two fungal extracts, While $\mathrm{Bc} 22$ down regulated compared to control. $a=$ control, HEPG2 liver-cancer cells without treatment, $b=$ HEPG2 liver -cancer cells treated with IC50 concentration of EAFE, $c=$ HEPG2 liver -cancer cells treated with IC50 of EAPE. P-value: versus the non-treated control group. Data represent the mean fold change \pm SD of triplicate experiments. * All data is analyzed by Graph pad prism (version 5.01) significantly different as compared to nontreated control cell at $\mathrm{P}<0.05$.

GC-MS is an effective method of identifying compounds that are present in the fungal extract. For EAFE and EAPE the GC-MS chromatography shows the presence of 30 compounds in each sample. In the same way as our findings, Gokhale et al. (2017) screened bioactive molecules of endophytic fungi by GCMS spectroscopy. The highest three compounds were (Diisooctyl phthalate; Disperse Blue 26 and 3-Benzo[g]quinoxalin-2-yl-propionic acid) for EADF and (Benzoic acid, 3,5-bis (1,1dimethylethyl)-4-hydroxy-methyl ester; 2Myristynoyl-glycinamide and Cinnamic acid, $p$ (tri methylsiloxy)-,methyl ester) for EADP with different relative proportion.
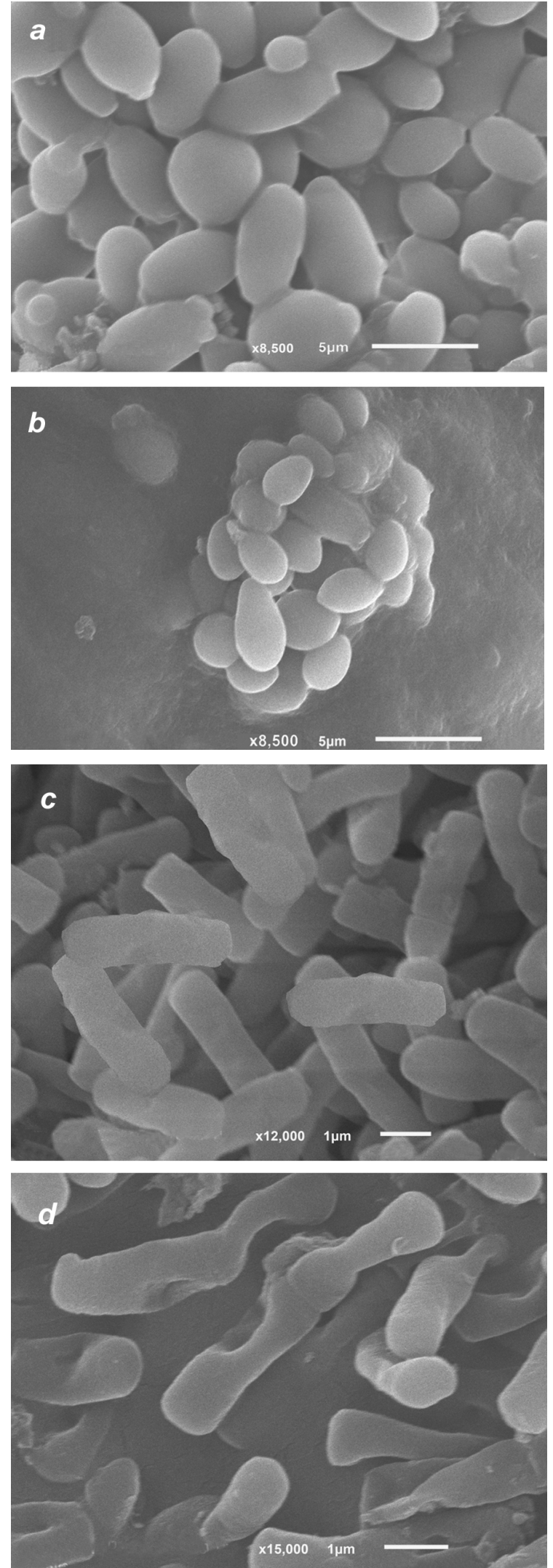

Figure 6. Scanning electron micrograph of treated C.albicans and B.cereus cells with EAPE. a: untreated C.albicans cells; b: treated C.albicans cells with EAPE; c: untreated B.cereus cells; d: treated B.cereus cells with EAPE. 

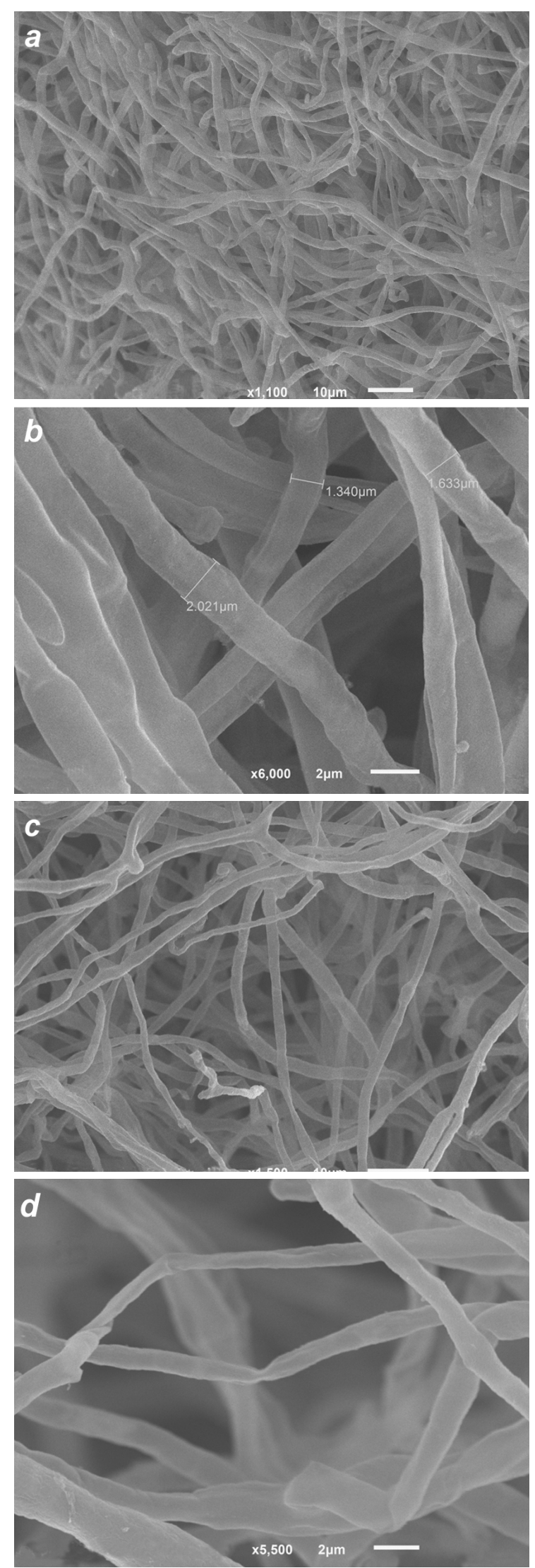

Figure 7. Scanning electron micrograph of treated $T$. mentagrophytes with EAFE. a,b: untreated T.mentagrophytes cells; c,d: treated T.mentagrophytes cells with EAFE.
Antioxidant, antimicrobial and antitumor activities of both extracts may be related to these active compounds. This was in accordance with the antioxidant and antimicrobial activities of di-isooctyl phthalate produced by Cassia angustifolia (medicinal plant) (Al-Marzoki et al., 2016).

In addition, it has also described Bauhinia variegate linn. from secondary metabolites. Leaf extract has demonstrated colon cancer antitumor activity (Gunalan et al., 2016). Similarly, Hazeldin et al. (2005) reported that 2\{4-[(7-Chloro-2-quinoxalinyl) oxyphenoxy] propionic acid and 2-[4-[(7-bromo-2-quinolinyl) oxy] phenoxy] propionic acid is the most highly analogues for antitumor agents. Park et al. (2001) have also reported a strong antimicrobial activity of benzoic acid for benzoic acid. As reported by Devereux et al. (2007), benzoic derivatives also have antitumor activity against human hepatic (HepG2), renal (A-498), and lung (A-549) cancer cell lines. Bashir et al. (2012) also demonstrated that cinnamic acid methyl ester (A. aspera), benzenepropanoic acid, and 3, 5-bis (1,1-dimethylethyl)-4-hydroxy-methyl ester have both antifungal and antioxidant activities.

\section{CONCLUSION}

This study showed that F.oxysporium and P.herbarum as novel endophytic fungi from U.picroides have significant antimicrobial, antioxidant and antitumor activities against HepG2 cancer cell line followed by gene expression analysis using (p53, Bax and Bcl-2) genes on real-time PCR which revealed the induction of apoptosis. Further studies were needed to confirm the efficacy of these endophytic fungal extracts by identifying the active components to be used as a promising drug thereafter.

\section{Acknowledgements}

This work was facilitated by of Scientific research Center and measurements (SRCM), Tanta University, Tanta, Egypt.

\section{Conflict of interest}

The authors declare that they have no competing interests. 


\section{References}

Ahmed D (2003). Current situation of the flora and vegetation of Nile Delta region. Msc. Thesis, Faculty of science, Tanta University, Egypt.

Alley MC, Scudiero DA, Monks A, Hursey ML, Czerwinski MJ and Fine DL (1988). Feasibility of drug screening with panels of human tumor cell lines using a microculturetetrazolium assay. Cancer Res., 48: 589-601.

Al-Marzoqi AH, Hadi MY and Hameed IH (2016). Determination of metabolites products by Cassia angustifolia and evaluate antimicrobial activity JPP J., 8(2): 25-48.

Aly HA, Edrada-Ebel R, Wary V,Muller WEG, Kozytska S, Hentschel U, Proksch P and Ebel R (2008). Bioactive metabolites from the endophytic fungus Ampelomyces $\mathrm{sp}$ isolated from the medicinal plant Urospermumpicroides.Phyto.chemist., 69: 1716-1725.

Bashir A, Ibrar K, Shumaila B and Sadiq A (2012). Chemical composition and antifungal, phytotoxic, brine shrimp cytotoxicity, insecticidal, and antibacterial activities of the essential oils of Acacia modesta. J Med Plants Res., 6(31): 4653-4659.

Cui JL, Guo SX and Xiao PG (2011). Antitumor and antimicrobial activities of endophytic fungi from medicinal parts of Aquilaiasinesis. ZJUS-B., 12(5): 38-392.

Devereux M, O'shea D, O'connor M, Grehan H, Connor G, McCANN M, Rosair G, Lyng

F, Kellette A, Walsh M, Egan D and Thati B (2007). Synthesis, catalase, superoxide dismutase and antitumour activities of copper(II) carboxylate complexes incorporating benzimidazole, 1,10phenanthroline and bipyridine ligands: $\mathrm{X}$-ray crystal structures of $\left[\mathrm{Cu}(\mathrm{BZA})_{2}(\right.$ bipy $\left.)\left(\mathrm{H}_{2} \mathrm{O}\right)\right]$, $\left[\mathrm{Cu}(\mathrm{SalH})_{2}(\mathrm{BZDH})_{2}\right]$ and $\left[\mathrm{Cu}\left(\mathrm{CH}_{3} \mathrm{COO}\right)_{2}(5,6-\right.$ $\mathrm{DMBZDH})_{2} \mathrm{~S}_{2} \quad\left(\mathrm{SalH}_{2}=\right.$ salicylic acid; $\mathrm{BZAH}=$ benzoic acid; $\mathrm{BZDH}=$ benzimidazole and 5,6-DMBZDH $=5,6$ dimethylbenzimidazole). Polyhedron., 26(25): 4073-4084.

El-Amier YA, Al-hadithy ON and Abdullah TJ (2016). Antioxidant and antimicrobial activity of different extracts obtained from aerial parts of Urospermumpicroides (L.) F.W.fromEgypt. J ADV Chem.Sci., 2(3): 299-301.

El-Ghazooly, MagedG., El-Lakany, Abdalla M., AbouShoer, Mohamed I, Aly, Amal H (2003). Chemical constituents of Helichrysumconglobatum growing in Egypt. Nat. Prod. Sci., 9(4): 231-219.

Glienke-Blanco C, Aguilar-Vildoso C I, CarnerioVieria M L, Vianna Barroso P A and Azevedo J L (2002).
Genetic variability in the endophytic fungus Guignardiacitricarpaisolated from citrus plants. Gene. Mol. Biol., 25(2):251-255.

Gokhale M, Verma M, Faraz R and Raj D (2017). Bioactive Molecules (GC-MS) of Endophytic fungi,Xylaria from Nyctanthes arbor-trists (Linn). H. K. B. J., 3(1):43-53.

Gunalan G, Vijayalakhshmi K, Tamilvannan T and Hopper W (2016). Anticancer activity of secondary metabolites from Bauhinia variegate linn. leaf- an in-silico approach. Indo American J Pharm. Res., 6(7): 6.

Hazeldine ST, Polin L, Kushner J, White K, Corbett TH, Biehl A and Horwitz JP(2005). Synthesis and biological evaluation of some analogs of the antitumor agents, 2-\{4-[(7-chloro-2quinoxalinyl)oxy]phenoxy\}propionic acid, and 2-\{4-[(7-bromo-2-

quinolinyl)oxy]phenoxy\}propionic acid. Bioorganic and Med.Chem. J., 13(4): 10691081.

Huang W Y, Cai, Y Z, Hyde, K D., Corke H and Sun M (2008). Biodiversity of endophytic fungi associated with 29 traditional chinese medicinal plants. Fungal div. J., 33:61-75.

Huang YJ, Wang JF, Li GL, Zheng ZH and SuWJ (2001). Antitumor and antifungal activities in endophytic fungi isolated from pharmaceutical plants Taxusmairei, Cephalataxus fortune and Torreyagrandis. FEMS Immunol Med. MIC., 31: 163-167.

Israel RK, Devanadera PKM, Mayor RBA, Cada ACM, Pecundo HM and Macabeo GPA (2019). Toxicity, Antibacterial, and Antioxidant Activities of Fungal Endophytes Colletotrichum and Nigrospora spp. Isolated from Uvaria grandiflora. Philippine J of Sci., 148(3):503-510.

Jalgaonwala R E, Mohite B V and Mahajan RT (2010). Evaluation of endophytes for their antimicrobial activity from indigenous medicinal plants belonging to North Maharashtra region India. Int. J. Pharma Biomedical Res., 1: 136-41.

kaya I, Yigit N and Benli (2008). Antimicrobial Activity of various extracts of OcimumBasilicumL. And observation of the inhibition effect on bacterial cells by use of scanning electron microscopy. Afr.J.Trad.CAM., 5(4):363-369.

Khan AL, Waqas M, Hussain J, Al-Harrasi A, Al-Rawahi A, Al-Hosni K, Kim MJ, Adnan M and Lee IN (2014). Endophytes Aspergillus caespitosus LK12 and Phoma sp. LK13 of Moringa peregrine produce gibberellins and improve rice plant growth. J Plant Interact., 9(1): 731-737.

Kharwar RN, Mishra A, Gong SK, Stierle A and Stierle D (2011). Anticancer compounds derived from 
fungal endophytes: their importance and future challenges. Nat. Prod. Rep, 28: 1208-1228.

Li p, Luo C, Sun W, Lu S, Mou Y, Peng Yand ZhouL (2011). In vitro antioxidant activities of polysaccharides from endophytic fungus Fusarium oxysporum Dzf17, J Microbiol. Res., 5(32): 5990-5993.

Lv YL, Zhang FS, Chen J, Cui JL, Xing Y, Li XD and Guo SX (2010). Diversity and antimicrobial activity of endophytic fungi associated with the alpine plant Saus-surea involucrate. Biol. Pharm. Bull., 33(8): 1300-1306.

Minirani Artica IA, Julistiono $\mathrm{H}$, Bermawie N, Riyanti El, Hashim and Hasan AEZ (2017). Anticancer activity test of ethyl acetate extract of endophytic fungi isolated from soursop leaf (Annonamuricata L). Asian Pac. J Trop. Med, 10(6): 566-571.

Mosmman T (1983). Rapid colorimetric assay for cellular growth and survival: application to proliferation and cytotoxicity assays. J Immunol. Methods, 65: 55-63.

Naruya S and Masatoshi N (1987). The Neighborjoining method: a new method for reconstructing phylogenetic tree. Mol. Biol.Evol., 4(4): 406-425.

Park ES, Moon WS, Song MJ, Kim NM, Chung KH and Yoon JS (2001). Antimicrobial activity of phenol and benzoic acid derivatives. Int.biodeterior. biodegradation, 47(4): 209-214.

Phongpaichit S, Rungjindamai N, Rukachaisirikul N and Sakayaroj J (2006). Antimicrobial activity in cultures of endophytic fungi isolated from Garcinia species. FEMSImmunol. Med. Microbiol., 48(3): 367-372.

Radhika P, Sastry B, Harica B and Madhu B (2008). Antimicrobial screening of Andrographis Paniculata (Acanthaceae) rot extracts. Res. Biotech. J., 3:62-63.

Rantaweera BP, Silva ED, Willias DE and Andersen RJ (2015). Antimicrobial activities of endophytic fungi obtained from the arid zone invasive plant Opuntia dillenii and the isolation of equisetin, from endophytic Fusarium sp. CAM J., 15(1): 220.

Rukshana MS, Doss A and Kumari P R T P (2017). Phytochemical screening and GC-MS analysis of Leaf extract of Pergulariadaemia (Forssk) Choiv. Asian J of Plant Sci. and Res., 7(1):9-15.

Selvin J, Joseph S, Asha KRT, manjusha WA, Sangeetha VS, Jayaseema DM, Antony MC and Vinitha AJD (2004). Antibacterial potential of antagonistic Streptomyces $s p$. Isolated from marine sponge Dendrillanigra. FEMS microbiology ecology, 20(2): 117-122.

Sivalokanathan S, Vijayababu MR and Balasubramanian MP (2006). Effects of Terminaliaarjuna bark extract on apoptosis of human hepatoma cell line HepG2. World J Gastroentro., 21(7):1018-1024.

Strobel G and Daisy B (2003). Bio prospecting for microbial endophytes and their natural products. Microbiol Mol. Biol. R, 67: 491-502.

Supaphon P, Phongpaichit S, Rukachaisirikul V and Sakayaroj J (2013). Antimicrobial potential of Endophytic fungi Derived from Three Seagrass Species: Cymodoceaserrulata, Halophila ovalis and Thalassiahemprichii. Plos one., 8(8).

Thompson JD, Higgins DG and Gibson TJ (1994). CLUSTALW, improving the sensitivity of progressive multiple alignment through sequence weighting, positions-specific gap penalties and weight matrix choice. Nucleic Acids Res., 22(22): 4673-4680.

Xu L, Zhou L, Zhao J, Li J, Li X and Wang J (2008). Fungal endophytes from Dioscoreazingiberensisrhizomes and their antibacterial activity. Lett. Appl. Microbiol., 46 (1): 68-72.

Yadav M, Yadav, Kumar S, Sharma D and Yadav J (2014). Evaluation of in vitro antimicrobial potential of endophytic fungi isolated from Eugenia Jambolana Lam. Intd. Pharm. Pharm. Sci., 6(5):208-11.

Yang J, Sun S and Yan Y (2010). a novel lipase gene cloned from exhibits enzymatic characteristics distinct from its previously identified family member. Biotechnoi. Lett., 32: 951-956.

Yang X, Gao X, Han F and Tan R (2005). Sulfation of a polysaccharide produced by a marine filamentous fungus Phomaherbarum YS4108 alters its antioxidant properetiesin vitro, Biophys. Acta., 1725: 120-127.

Yb Ji, Gao SY, Ji CF and Zou X (2008). Induction of apoptosis in HepG2 cells by Solanine and $\mathrm{Bcl}-2$ protein. J Ethnopharmacol., 115(2): 194-202.

Yu J, Mohawed S, Bhatnagar D and Cleveland T (2003). Substrate-induced lipase gene expression and aflatoxin production in Aspergillus parasiticus and Aspergillus flavus. Appl. Microbiol., 95: 1334-1342.

Zakaria Y, Rahmat A, Pihie AHL, Abdullah NR and Houghton PJ (2009). Eurycomanone induce apoptosis in HepG2 cells via up-regulation of p53. Cancer Cell Int., 9(1): 16. 


\section{Egyptian Association for Cancer Research (EACR)}

http://eacr.tanta.edu.eg/

EACR is an NGO society that was declared by the Ministry of Social Solidarity (Egypt) No. 1938 in 19/11/2014 based on the initiative of Prof. Mohamed Labib Salem, the current Chairman of EACR. EACR aims primarily to assist researchers, in particular young researchers in the field of cancer research through workshops, seminars and conferences. Its first international annual conference entitled "Anti-Cancer Drug Discovery" was successfully organized in April 2019 (http://acdd.tanta.edu.eg). Additionally, EACR aims to raise the awareness of the society about the importance of scientific research in the field of cancer research in prediction, early diagnosis and treatment of cancer. EACR is also keen to outreach the scientific community with periodicals and news on cancer research including peer-reviewed scientific journals for the publication of cutting-edge research. The official scientific journal of EACR is "International Journal of Cancer and biomedical Research (IJCBR: https://jcbr.journals.ekb.eg) was successfully issued in 2017 and has been sponsored by the Egyptian Knowledge Bank (EKB: www.ekb.eg).

\section{EACR Chairman,}

Prof. Mohamed Labib Salem, PhD

Professor of Immunology

Faculty of Science, Tanta Universiy, Egypt 


\section{Editor-in-Chief}

Mohamed Labib Salem, PhD

Tanta University, Egypt

\section{Managing Editor}

Nehal Elmashad, MD

Tanta University, Egypt

Nabil Mohy Eldin, PhD

Kafrelsheikh University, Egypt

Doaa Al-Ghareeb, PhD

Alexandria University, Egypt

Abdel-Aziz Zidan, PhD

Damanhour University, Egypt

Wesam Meshrif, PhD

Tanta University, Egypt

Rasha Eraky, MD

Tanta University, Egypt

\section{Associate Editor}

Hesham Tawfik

Tanta University, Egypt

Mostafa El-Sheekh

Tanta University, Egypt

Yousry Albolkiny, PhD

Tanta University, Egypt

Gamal Badr

Assuit University, Egypt

Elsayed Salim

Tanta University, Egypt

Essam Elshiekh

Tanta Cancer Center, Egypt

\section{Editorial Board}

\author{
Alberto Montero \\ Taussig Cancer Center, \\ Cleveland, USA \\ Marcela Diaz \\ Cleveland Clinic Foundation, USA \\ Yi Zhang \\ Zhengzhou University, China \\ Shengdian Wang \\ Chinese Academy of Sciences, \\ China \\ Faris Alenzi \\ Prince Sattam bin Abdulaziz \\ University, KSA \\ Mark Robunstein \\ Medical University of South \\ Carolina, USA \\ Mamdooh Ghoneum, DSc \\ Charles Drew University of \\ Medicine \& Science, USA
}

Natarajan Muthusamy, DVM

The Ohio State University, USA

Hideki Kasuya MD, PhD,

FACS

Nagoya University, Japan

Sherif El-Khamisy, MD

Sheffield University, UK

Mohamed Abou-El-Enein,

MD

Charité Universitätsmedizin

Berlin, Germany

Alaa Eldin Almostafa, MD

McGill University, Canada

\section{Amr Amin}

United Arab Emirates

University, UAE

AbdelRahman Zekri

National Cancer Institute, Egypt

Mohamed Attia, MD

Tanta University, Egypt

Mohamed Elshanshory, MD

Tanta University, Egypt

Hussein Khamis

Alexandria University, Egypt

Magdy Mahfouz

Kafr Elsheikh University, Egypt

Ehab Elbedewey

Tanta University, Egypt

Abeer Badr

Cairo University, Egypt

Nadia Hamdy, PharmD

Ain Shams University, Egypt

Ibrahim El-Sayed

Menoufia University, Egypt

Tarek Aboul-Fadl, PharmD

Assiut University, Egypt

Mohamed Noureldin

Banaha University, Egypt

Haiam Abou Elela

National Institute of

Oceanography and Fisherie,

Egypt

Sameh Ali, MD

Nationa Liver Institute, Egypt

Maha EL-Demellawi

City for Scientific Research \&

Technology Applications, Egypt

Desouky A Abd-El-Haleem

City for Scientific Research \&

Technology Applications, Egypt
Ashraf Tabll

National Research Center, Egypt

Wael Lotfy, MD

Alexandria University, Egypt

Olfat Gadallah, MD

Tanta University, Egypt

Nahla Shoukry

Suez University, Egypt

Medhat Eldenary

Tanta University, Egypt

Nagla Sarhan, MD

Tanta University, Egypt

Naglaa Fathy, MD

Zagazik University, Egypt

Azza Hasan Mohamed Menufia University, Egypt

Nanees Gamal Eldin

Tanta University, Egypt

Mohamed Mansour, UK

Sabbah Hammoury

Alexandria Ayadi Almostaqbal

Oncology Hospital, Egypt

Nehal Aboulfotoh

Zewail City for Science and

Technology, Cairo, Egypt

Amir Elkhami

Galaxo, San Francisco, USA

Rabab Khairat

National Research Center,

Giza, Egypt

Ahmed Alzohairy

Zagazi University, Egypt

Wgady Khalil

National Research Center, Egypt

Sayed Bakry

Alazhar University, Egypt

Mohamed Ghanem, MD

Kafr Elshikh University, Egypt

Mohamed Salama, MD

Mansoura University, Egypt

Mona Marie, MD

Alexandria University, Egypt

\section{For more information, contact}

Hamdi Kandil

Tanta University, Egypt

Email: ljcbr100@gmail.com 